\title{
PENGARUH KEPADATAN KANDANG TERHADAP BOBOT HIDUP, KARKAS, DAN GIBLET BROILER UMUR 14-28 HARI DI CLOSED HOUSE
}

\author{
The Effect of Stocking Density on Live Weight, Carcass, and Giblet of Broiler Aged 14--28 Days \\ in Closed House
}

\author{
Nurul Barruni, Syahrio Tantalo, Dian Septinova, Khaira Nova \\ Departement of Animal Husbandry, Faculty of Agriculture, University of Lampung \\ Jl. Prof. Dr. Soemantri Brojonegoro No.1 Gedong Meneng Bandar Lampung 35145 \\ e-mail : barruninurul@gmail.com
}

\begin{abstract}
This study aimed to study the effect of stocking density on live weight, carcasses and giblets of broiler in closed houses; and to determine the best stocking density on live weight, carcass and giblet of broiler in a closed house. This research was conducted in April-May 2019 for 28 days with 14 days of treatments period (14-28 days) at PT. Charoen Pokphand (Kandang Bandara 2) located in Bangun Sari hamlet, Way Sari Village, Natar District, Lampung Selatan Regency. This study used a Completely Randomized Design with four treatments, of stocking density of 15 heads $/ \mathrm{m}^{2}(\mathrm{P} 1)$, stocking density of 17 heads $/ \mathrm{m}^{2}$ (P2), stocking density of 19 heads $/ \mathrm{m}^{2}(\mathrm{P} 3)$, and stocking density of 21 heads $/ \mathrm{m}^{2}(\mathrm{P} 4)$, with five replications for each treatment. The data obtained were analyzed using analysis of variance at $5 \%$ level. The result of the analysis of variance showed that the different stocking density had no significant effect on the live weight, carcasses, and giblet of broiler at 28 days of age in the closed house.
\end{abstract}

Keywords: Carcass, Closed house, Giblet, Live weight, Stocking density

\section{ABSTRAK}

Penelitian ini bertujuan untuk mempelajari pengaruh kepadatan kandang terhadap bobot hidup, karkas dan giblet broiler di closed house; dan mengetahui kepadatan kandang yang terbaik terhadap bobot hidup, karkas dan giblet broiler di closed house. Penelitian ini dilaksanakan pada bulan April-Mei 2019 selama 28 hari dengan 14 hari perlakuan (14-28 hari) di PT. Charoen Pokphand (Kandang Bandara 2) Dusun Bangun Sari, Desa Way Sari, Kecamatan Natar, Kabupaten Lampung Selatan. Penelitian ini menggunakan Rancangan Acak Lengkap dengan empat perlakuan yaitu kepadatan kandang $15 \mathrm{ekor} / \mathrm{m}^{2}(\mathrm{P} 1)$, kepadatan kandang $17 \mathrm{ekor} / \mathrm{m}^{2}$ (P2), kepadatan kandang $19 \mathrm{ekor} / \mathrm{m}^{2}(\mathrm{P} 3)$ dan kepadatan kandang $21 \mathrm{ekor} / \mathrm{m}^{2}(\mathrm{P} 4)$ dengan lima ulangan. Data yang diperoleh dianalisis menggunakan analisis ragam pada taraf $5 \%$. Hasil analisis ragam menunjukkan bahwa pada kepadatan kandang yang berbeda tidak berpengaruh nyata terhadap bobot hidup, karkas dan giblet broiler umur 28 hari di closed house.

Kata Kunci: Karkas, Closed house, Giblet, Bobot hidup, Kepadatan kandang

\section{PENDAHULUAN}

Seiring dengan perkembangan waktu, pertambahan jumlah penduduk, peningkatan pendapatan, dan kesadaran masyarakat akan arti pentingnya gizi bagi kesehatan tubuh, maka permintaan masyarakat akan kebutuhan pangan salah satunya sumber protein hewani semakin meningkat. Hal ini dapat dilihat dengan meningkatnya konsumsi protein per kapita sehari untuk daging pada 2016 sebesar 3,35 g, meningkat sebesar 7,03\% dibandingkan konsumsi pada 2015 sebesar 3,13 g (Dirjen Peternakan dan Kesehatan Hewan, 2017). Salah satu pangan sumber protein hewani yang digemari oleh masyarakat adalah daging ayam. Daging ayam yang dikonsumsi biasanya berasal dari daging broiler. Broiler mempunyai sifat tenang, bentuk tubuh besar, pertumbuhan cepat, kulit putih, dan bulu merapat ke tubuh (Suprijatna et al., 2005). Keberhasilan usaha peternakan tidak terlepas dari manajemen pemeliharaan yang baik dengan kepadatan kandang yang sesuai untuk pertumbuhan broiler dalam rangka peningkatan produktivitas. Peningkatan produktivitas nyatanya tidak diimbangi dengan luasnya lahan yang digunakan sebagai peternakan. Peningkatan jumlah ayam tiap meter persegi diharapkan dapat meningkatkan produktivitas, serta akan berpengaruh pada kenyamanan ayam karena kandang yang terlalu padat akan mempengaruhi suhu dan kelembaban.

Saat ini penggunaan closed house telah menarik perhatian peternak ayam komersial. Closed house merupakan suatu rancangan kandang ayam yang tidak terpengaruh oleh lingkungan dari luar kandang. Sistem kandang closed house memiliki 
keunggulan yaitu memudahkan pengawasan, suhu dan kelembabannya dapat diatur, memiliki pengaturan cahaya dan mempunyai ventilasi yang baik sehingga penyebaran penyakit mudah diatasi. Kelebihan lain dari penggunaan closed house adalah dapat menggunakan kepadatan kandang dengan jumlah yang tinggi.

Kepadatan kandang dapat mempengaruhi keseragaman bobot tubuh. Kandang yang terlalu padat menyebabkan ayam tidak mendapatkan pakan dan minum secara serentak. Ketidakseragaman ini dapat menimbulkan perilaku dominasi pada sekelompok ayam. Penggunaan closed house dapat menekan dampak perubahan suhu sehingga pertumbuhan broiler dapat optimal. Pertumbuhan broiler yang optimal akan berakibat pada produksi bobot hidup, bobot karkas, dan bobot giblet yang dihasilkan. Laju pertumbuhan pada broiler ditunjang juga oleh kecukupan nutrisi yang dikonsumsi oleh broiler. Kecukupan nutrisi ini erat hubungannya dengan kandungan gizi dalam pakan dan kemampuan usus dalam menyerap nutrisi pada pakan tersebut. Untuk itu dilakukan juga pengukuran bobot giblet guna melihat metabolisme tubuh dan kerja otot broiler.

Sehubungan dengan kepadatan kandang di closed house tersebut sampai saat ini belum banyak diketahui. Penggunaan closed house dapat menekan kondisi lingkungan kandang sehingga broiler yang dipelihara tetap berada dalam kondisi nyaman. Oleh sebab itu, penulis tertarik untuk melakukan penelitian tentang pengaruh kepadatan kandang terhadap bobot hidup, karkas, dan giblet.

\section{MATERI DAN METODE}

Penelitian ini dilaksanakan pada bulan April-Mei 2019 selama 28 hari dengan 14 hari perlakuan (14-28 hari) di PT. Charoen Pokphand (Kandang Bandara 2) Dusun Bangun Sari, Desa Way Sari, Kecamatan Natar, Kabupaten Lampung Selatan.

\section{Bahan dan Alat}

Bahan yang digunakan adalah DOC broiler strain Cobb dengan merek dagang CP 707 produksi PT. Charoen Pokphand Breeding Division. Broiler mendapat perlakuan pada umur 14-28 hari sebanyak 360 ekor, dengan rata-rata bobot awal broiler umur 14 hari $(442,13 \pm 13,46$ g/ekor) dan koefisien keragaman sebesar 3,04\%. Ransum yang digunakan dalam penelitian ini adalah ransum broiler komersil dengan kode pakan $\mathrm{H} 00$ untuk fase starter (1-13) dan H11 untuk fase finisher (14panen) oleh PT. Chareon Pokphand Feedmill yang akan diberikan sesuai dengan kebutuhan konsumsi ransum broiler Cobb-vantress selama 14 hari pemeliharaan (14-28 hari). Peralatan yang digunakan dalam penelitian ini antara lain babychick feeder, pan feeder, nipple drinker, heater, timbangan kapasitas $5 \mathrm{~kg}$, sekat dari kayu dan jaring untuk penyekat antar perlakuan, thermohygrometer, stetoskop, thermometer rektal, alat kebersihan, dan alat tulis untuk pengambilan data.

\section{Metode}

\section{Rancangan Percobaan}

Penelitian ini menggunakan rancangan acak lengkap (RAL) yang terdiri dari 4 perlakuan dan 5 ulangan. Perlakuan yang diberikan adalah kepadatan kandang 15 ekor $/ \mathrm{m}^{2}$ (P1), kepadatan kandang 17 ekor/m² (P2), kepadatan kandang 19 ekor/m² (P3), dan kepadatan kandang 21 ekor $/ \mathrm{m}^{2}$ (P4).

\section{Analisis Data}

Data dianalisis ragam pada taraf 5\%. Bila menunjukkan pengaruh yang nyata pada taraf $5 \%$, maka dilanjutkan dengan uji jarak berganda Duncan (Steel dan Torrie, 1995).

\section{Peubah yang Diamati}

Peubah yang diamati pada penelitian ini adalah bobot hidup, karkas, dan giblet broiler. Setiap petak diambil sampel sebanyak 1 ekor dengan total jumlah sampel yang digunakan yaitu 20 ekor. Bobot hidup diperoleh dari hasil penimbangan ayam setelah dipuasakan selama \pm 6 jam. Bobot karkas dihitung dengan cara menimbang ayam tanpa darah, bulu, kepala sampai batas pangkal leher, kaki sampai batas lutut, dan organ dalam. Bobot giblet diperoleh dari penimbangan bobot hati, jantung, dan gizzard yang telah dibersihkan (Soeparno, 1994).

\section{HASIL DAN PEMBAHASAN}

\section{Pengaruh Perlakuan terhadap Bobot Hidup}

Rata-rata bobot hidup broiler umur 28 hari berkisar antara 1.155,20-1.183,80 g/ekor (Tabel 1). Hasil analisis ragam menunjukkan bahwa kepadatan kandang berpengaruh tidak nyata $(\mathrm{P}>0,05)$ terhadap bobot hidup broiler umur 28 hari. Rata-rata bobot hidup (Tabel 1) broiler umur 28 hari berturut-turut pada kepadatan kandang 15 ekor $/ \mathrm{m}^{2}(1.155,20$ g/ekor) atau $17 \mathrm{~kg} / \mathrm{m}^{2}, 17$ ekor $/ \mathrm{m}^{2}$ (1.177,20 g/ekor) atau $20 \mathrm{~kg} / \mathrm{m}^{2}, 19 \mathrm{ekor} / \mathrm{m}^{2}(1.171,00 \mathrm{~g} /$ ekor $)$ atau $22 \mathrm{~kg} / \mathrm{m}^{2}, 15$ ekor/m ${ }^{2}(1.183,80$ g/ekor $)$ atau 25 $\mathrm{kg} / \mathrm{m}^{2}$.

Tidak berbeda nyatanya bobot hidup broiler diduga dengan kepadatan kandang sampai dengan 21 ekor $/ \mathrm{m}^{2}$ masih membuat ayam merasa nyaman. Rataan suhu dan kelembaban selama penelitian dalam kandang sebesar $26,98^{\circ} \mathrm{C}$ dan $83,29 \%$. Menurut Info Medion (2019), suhu dan kelembaban kandang penelitian tersebut dapat berdampak terhadap heat stress. Walaupun demikian, ayam yang dipelihara di closed house sampai dengan kepadatan kandang 21 ekor $/ \mathrm{m}^{2}$ tidak 
menunjukkan adanya heat stress (stres panas). Hal ini disebabkan oleh adanya chilling effect. Menurut Info Medion (2019), dalam closed house terdapat chilling effect yaitu efek penurunan suhu yang dirasakan ayam akibat kecepatan angin yang berhembus. Semakin tinggi angin berhembus, maka chilling effect yang dirasakan semakin besar atau suhu efektif semakin rendah.

Tabel 1. Rata-rata bobot hidup, karkas, dan giblet broiler

\begin{tabular}{ccccc}
\hline \multirow{2}{*}{ Peubah } & \multicolumn{4}{c}{ Perlakuan } \\
\cline { 2 - 5 } & $\mathrm{P} 1$ & $\mathrm{P} 2$ & $\mathrm{P} 3$ & $\mathrm{P} 4$ \\
\hline Bobot hidup (g/ekor) & $1.155,20 \pm 33,99$ & $1.177,20 \pm 34,31$ & $1.171,00 \pm 34,22$ & $1.183,80 \pm 34,41$ \\
Bobot karkas (g/ekor) & $779,2 \pm 27,91$ & $812,2 \pm 28,50$ & $787 \pm 28,05$ & $795,8 \pm 28,21$ \\
Bobot giblet (g/ekor) & $61,0 \pm 7,81$ & $65,4 \pm 8,09$ & $67,8 \pm 8,23$ & $65,2 \pm 8,07$ \\
\hline
\end{tabular}

Keterangan :

P1: kepadatan kandang $15 \mathrm{ekor} / \mathrm{m}^{2}$

P2: kepadatan kandang $17 \mathrm{ekor} / \mathrm{m}^{2}$

P3: kepadatan kandang $19 \mathrm{ekor} / \mathrm{m}^{2}$

P4: kepadatan kandang $21 \mathrm{ekor} / \mathrm{m}^{2}$

Suhu efektif adalah suhu yang dirasakan oleh tubuh ayam yang dipengaruhi oleh suhu ruangan, kelembaban, dan kecepatan angin dalam kandang. Lebih tingginya suhu dan kelembaban dari zona nyaman broiler menurut Tamalludin (2014) yaitu $24-25^{\circ} \mathrm{C}$ dan $60-70 \%$ diakibatkan oleh kurang maksimalnya fungsi ventilasi kandang. Menurut Fadillah (2006), fungsi ventilasi kandang adalah menghilangkan panas yang berlebihan dan menghilangkan kelebihan kelembaban, salah satu faktor yang mempengaruhi sistem ventilasi di kandang tertutup (closed house) adalah kemampuan operator kandang dalam mengatur kecepatan aliran udara dalam kandang. Menurut Wurlina et al. (2011), closed house merupakan kandang sistem tertutup yang dapat menjamin keamanan biologis pada ayam seperti kontak dengan organisme menggunakan pengaturan ventilasi yang baik sehingga suhu di dalam kandang menjadi lebih rendah dibanding suhu luar kandang, kelembaban, kecepatan angin dan cahaya yang masuk ke dalam kandang dapat diatur secara optimal sehingga tercipta kondisi yang nyaman bagi ayam. Hal ini akan dapat menghindari stres pada ayam secara berlebihan.

Menurut Blakely dan Bade (1998), faktor yang mempengaruhi bobot hidup broiler adalah konsumsi ransum, bila konsumsi ransum tinggi maka bobot hidup akan tinggi. Pada penelitian ini konsumsi ransum dengan kepadatan kandang 17, 19, dan 21 ekor $/ \mathrm{m}^{2}$ nyata lebih tinggi dibandingkan kepadatan kandang $15 \mathrm{ekor} / \mathrm{m}^{2}$, namun bobot hidup kepadatan kandang 17,19 , dan $21 \mathrm{ekor} / \mathrm{m}^{2}$ ternyata tidak berbeda nyata dengan kepadatan kandang 15 ekor $/ \mathrm{m}^{2}$. Pada kepadatan kandang $15 \mathrm{ekor} / \mathrm{m}^{2}$ konsumsi ransum dan serat kasar lebih rendah dibandingkan dengan konsumsi ransum dan serat kasar pada kepadatan kandang 17, 19, dan 21 ekor/ $\mathrm{m}^{2}$. Hal ini diduga menyebabkan kecernaan ransum broiler pada kepadatan kandang 15, 17, 19, dan $21 \mathrm{ekor} / \mathrm{m}^{2}$ relatif sama. Hal tersebut menyebabkan bobot hidup berbeda nyata. Walaupun kepadatan kandang tidak berbeda nyata, namun bobot hidup pada kepadatan kandang 17, 19, dan $21 \mathrm{ekor} / \mathrm{m}^{2}$ cenderung lebih tinggi dibandingkan kepadatan kandang $15 \mathrm{ekor} / \mathrm{m}^{2}$.

\section{Pengaruh Perlakuan terhadap Bobot Karkas}

Rata-rata bobot karkas broiler umur 28 hari berkisar antara 779,2-812,2 g/ekor. Hasil analisis ragam menunjukkan bahwa kepadatan kandang berbeda tidak nyata $(\mathrm{P}>0,05)$ terhadap bobot karkas broiler umur 28 hari. Tidak berbeda nyatanya bobot karkas broiler pada kepadatan kandang yang berbeda ini diduga disebabkan oleh bobot hidup yang juga tidak berbeda nyata. Menurut Haroen (2003), pencapaian bobot karkas sangat berkaitan dengan bobot hidup dan pertambahan bobot badan. Bobot hidup rendah akan menghasilkan bobot karkas rendah karena komponen utama karkas adalah tulang dan otot.

Berdasarkan Tabel 1 dapat diketahui kisaran persentase karkas broiler adalah antara 67$69 \%$. Hal ini sesuai dengan pendapat Kurtini et al. (2014) yang menyatakan bahwa rata-rata bobot karkas berkisar antara $65-75 \%$ dari bobot hidup ayam pedaging waktu siap potong. Tidak berbeda nyata bobot karkas juga dipengaruhi oleh kandungan nutrisi ransum yang diberikan. Menurut Han dan Baker (1994), broiler yang mengkonsumsi protein dan energi metabolisme yang sama akan menghasilkan bobot karkas yang tidak berbeda.

Banyak faktor yang dapat mempengaruhi nilai bobot karkas selain bobot hidup. Menurut Soeparno (1994), faktor lingkungan juga ikut mempengaruhi laju pertumbuhan, komposisi bobot karkas dan persentase karkas biasanya meningkat seiring meningkatnya bobot hidup. Tidak berbeda nyata bobot karkas broiler juga diduga akibat pemeliharaan broiler yang dilakukan di kandang sistem closed house tidak menunjukkan adanya tanda-tanda bahwa ayam mengalami stres sehingga 
kepadatan kandang 15 ekor $/ \mathrm{m}^{2}$ sampai kepadatan kandang $21 \mathrm{ekor} / \mathrm{m}^{2}$ tidak berpengaruh terhadap pertumbuhan karkas broiler.

\section{Pengaruh Perlakuan terhadap Bobot Giblet}

Rata-rata bobot giblet broiler umur

hari berkisar antara 61,0-67,8 g/ekor. Hasil analisis ragam menunjukkan bahwa kepadatan kandang tidak berpengaruh nyata $(\mathrm{P}>0,05)$ terhadap bobot giblet broiler umur 28 hari. Tidak berbeda nyatanya bobot giblet broiler pada kepadatan kandang yang berbeda diduga disebabkan oleh bobot hidup dan bobot karkas yang juga tidak berbeda nyata. Hal ini sesuai dengan pendapat Rasyaf (2011), bobot giblet meningkat dengan meningkatnya bobot karkas, walaupun persentase terhadap bobot hidup ayam akan menurun. Menurut Setiadi et al. (2013), bobot hidup mempengaruhi bobot giblet, semakin besar bobot hidup maka bobot giblet akan meningkat.

Tidak berbeda nyatanya bobot giblet diduga dipengaruhi oleh kandungan nutrisi ransum terutama kandungan serat kasar. Kandungan serat kasar yang digunakan selama penelitian adalah $5,25 \%$. Konsumsi serat kasar dari keempat perlakuan menunjukkan adanya perbedaan yang nyata. Akan tetapi faktanya pada penelitian ini ternyata kepadatan kandang yang mempengaruhi konsumsi serat kasar tidak berdampak pada bobot giblet yang tidak berbeda nyata. Hal tersebut disebabkan oleh kandungan serat kasar pada ransum masih dalam batasan normal. Menurut SNI (2018), kandungan serat kasar ransum untuk broiler adalah 5-6\%. Setiadi et al. (2013) juga menerangkan bahwa kandungan serat kasar dalam batas toleransi yang diperbolehkan untuk unggas yaitu tidak lebih dari $6 \%$.

Salah satu yang mempengaruhi bobot giblet adalah faktor lingkungan. Suhu lingkungan juga mempengaruhi suhu tubuh broiler yang dapat dilihat dari rata-rata suhu rektal broiler selama penelitian yaitu $41,22^{\circ} \mathrm{C}$ dengan kisaran suhu rektal adalah $41,5-41,9^{\circ} \mathrm{C}$ (Smith dan Mangkoewidjojo, 1988). Hal ini menunjukkan bahwa suhu rektal dalam penelitian berada pada kisaran suhu di bawah standar sehingga masih dikatakan normal. Semakin tingginya suhu lingkungan, temperatur tubuh ayam semakin tinggi karena semakin tingginya metabolisme tubuh ayam dalam mengatasi tingginya suhu lingkungan (Sulistyoningsih, 2005).

Suhu lingkungan juga dapat mempengaruhi kondisi tubuh broiler secara langsung, seperti terjadinya peningkatan frekuensi nafas. Ketika broiler berada dalam kandang yang suhunya tinggi, peningkatan kecepatan pernafasan (panting) merupakan cara utama untuk menurunkan suhu tubuh. Rata-rata frekuensi pernafasan broiler penelitian adalah $\quad 58,26 \mathrm{kali} / \mathrm{menit}$, lebih tinggi dari Smith dan Mangkoewidjojo (1988) yaitu 20-35 kali/menit. Perbedaan ini disebabkan oleh broiler penelitian sedang mengalami panting karena suhu dan kelembaban kandang penelitian lebih tinggi dari keadaan normal $\left(24-25^{\circ} \mathrm{C}\right.$ dan $\left.60-70 \%\right)$ (Tamalludin, 2014). Peningkatan kecepatan pernafasan (panting) akan menyebabkan terjadinya pemborosan energi dalam tubuh broiler. Menurut Hetland et al. (2005), saat ransum masuk ke dalam tubuh akan terjadi proses metabolisme. Proses metabolisme ini akan mempengaruhi aktivitas kerja dan bobot dari gizzard, hati, dan jantung.

Gizzard merupakan organ yang berperan penting untuk menghancurkan partikel-partikel makanan menjadi lebih kecil sehingga mudah dicerna oleh tubuh (Jumiati et al., 2017). Organ jantung memungkinkan terjadinya peredaran darah ke seluruh tubuh dan secara efisien ke dalam paruparu untuk pergantian $\mathrm{O}_{2}$ dan $\mathrm{CO}_{2}$ dalam menyokong metabolis dalam tubuh. Menurut Ressang (1984), ukuran jantung dipengaruhi oleh jenis, umur, besar dan aktivitas hewan. Jumiati et al. (2017) menambahkan bahwa hati memiliki beberapa fungsi yaitu pertukaran zat dari protein, lemak, sekresi empedu, detoksifikasi senyawa-senyawa yang beracun dan ekskresi senyawa-senyawa metabolit yang tidak berguna lagi. Broiler yang memiliki hati yang normal akan tumbuh dengan baik.

\section{SIMPULAN DAN SARAN}

\section{Simpulan}

Berdasarkan hasil penelitian dan pembahasan dapat disimpulkan bahwa kepadatan kandang broiler $15 \mathrm{ekor} / \mathrm{m}^{2}, 17 \mathrm{ekor} / \mathrm{m}^{2}$,

19 ekor $/ \mathrm{m}^{2}$, dan 21 ekor $/ \mathrm{m}^{2}$ di closed house berpengaruh tidak nyata terhadap bobot hidup, bobot karkas dan bobot giblet broiler.

\section{Saran}

Saran yang dianjurkan penulis berdasarkan hasil penelitian ini adalah peternak dapat menggunakan kepadatan kandang hingga kepadatan kandang $21 \mathrm{ekor} / \mathrm{m}^{2}$.

\section{DAFTAR PUSTAKA}

Blakely, J., dan D. H. Bade. 1998. Ilmu Peternakan. Edisi ke-4. Gadjah Mada University Press. Yogyakarta.

Direktorat Jendral Peternakan dan Kesehatan Hewan Kementerian Pertanian. 2017. Statistik Peternakan dan Kesehatan Hewan. http://ditjenpkh. pertanian.go.id. Diakses pada Senin 24 Juni 2019.

Fadillah, R. 2006. Panduan Lengkap Sukses Beternak Ayam Broiler. Agro Media Pustaka. Jakarta.

Han Y. dan D. H, Baker. 1994. Digestible Lysine Requirement of Male and Female Broiler 
Chicks during the Period Three to Six Weeks Posthatching. Poultry Sci. 73:1739-1745.

Haroen, U. 2003. Respon Ayam Broiler yang Diberi Tepung Daun Sengon (Albizzia falcataria) dalam Ransum terhadap Pertumbuhan dan Hasil Karkas. JIIP. 6(1): 34-41.

Hetland, H., B. Svihus and M. Choctt. 2005. Role of Insoluble Fiber on Gizzard Activity in Layers. Poultry Res. 14: 38-46.

Info Medion. 2019. Closed House, Solusi Peningkatan Performa Ayam. http://info.medion.co.id/index.php/artikel/39tata-laksana/2305-closed-house-solusipeningkatan-performa-ayam. Diakses pada 9 Juni 2019.

Jumiati, S., Nuraini, dan R. Aka. 2017. Bobot Potong, Karkas, Giblet, Lemak Abdominal Ayam Broiler yang Diberikan Temulawak dalam Pakan. JITRO. 4(3): 11-19.

Kurtini, T., K. Nova dan D. Septinova. 2014. Produksi Ternak Unggas. Buku Ajar. Jurusan Peternakan. Fakultas Pertanian. Universitas Lampung. Lampung.

PT. Chareon Pokphand Indonesia. 2006. Managemen Broiler Modern. Kiat-kiat Memperbaiki FCR. Technical Service dan Development Departement, Jakarta.

Rasyaf, M. 2011. Panduan Beternak Ayam Pedaging. Penebar Swadaya. Jakarta.

Ressang, A. A. 1984. Patologi Khusus Veteriner. Institut Pertanian Bogor. Bogor.

SNI. 2018. Pakan Ayam Ras Pedaging (Broiler Finisher). Nomor SNI 8173.3.
Smith, B.J. dan Mangkoewidjojo, S. 1988. Pemeliharaan, Pembiakan, dan Penggunaan Hewan Coba di Daerah Tropis. Universitas Indonesia Press. Jakarta.

Setiadi, D., K. Nova, dan S. Tantalo. 2013. Perbandingan Bobot Hidup, Karkas, Giblet, dan Lemak Abdominal Ayam Jantan Tipe Medium dengan Strain Berbeda yang Diberi Ransum Komersial Broiler. JIPT. 1(2): 1-7.

Soeparno. 1994. Pilihan Produksi Daging Sapi dan Teknologi Prosesing Daging Unggas. Fakultas Peternakan. Universitas Gadjah Mada. Yogyakarta.

Steel, R. G. D. dan J. H. Torrie. 1995. Prinsip dan Prosedur Statistika. PT. Gramedia Pustaka Utama. Jakarta.

Sulistyoningsih, M. 2005. Respon Fisiologis Ayam Broiler Periode Starter akibat Cekaman Temperatur dan Awal Pemberian Pakan yang Berbeda. Majalah Ilmiah Lontar. 19(3): 7487.

Suprijatna, E., U. Atmomarsono, dan P. Kartasudjana. 2005. Ilmu Dasar Ternak Unggas. Cetakan ke-1. Penebar Swadaya. Jakarta.

Tamalludin, F. 2014. Ayam Broiler, 22 Hari Panen Lebih Untung. Penebar Swadaya. Jakarta.

Wurlina, D.K. Meles dan E. Paramyta. 2011. Peningkatan Usaha Peternakan Ayam Potong dengan Teknologi Kandang Tertutup (Closed House Methode) di Kabupaten Jombang Melalui Kegiatan Iptekda-LIPI. 